Jurnal Kejaora: Jurnal Kesehatan Jasmani dan Olah Raga

ISSN: 2541-5042 (Online)

ISSN: 2503-2976 (Print)

Volume 5 Nomor 2, Edisi November 2020

\title{
ANALISIS BIOMEKANIKA PERGERAKAN PINGGUL PENARI BAPANG
}

\author{
Dino Nofianto', Muhammad Agus Sahbana², Nurida Finahari ${ }^{3}$ \\ 1,2,3 Prodi Teknik Mesin Universitas Widyagama Malang \\ E-mail: dino.nofianto@merck.com¹, sahbana@widyagama.ac.id², nfinahari@widyagama.ac.id³ \\ DOI: https://doi.org/10.36526/kejaora.v5i2.993
}

\begin{abstract}
ABSTRAK
Biomekanika didefinisikan sebagai ilmu aplikasi mekanika pada sistem biologi. Kompleksitas sistem tubuh makhluk hidup merupakan gambaran awal kompleksitas pembelajaran dan penelitian biomekanika. Pergerakan pinggul penari memegang peran penting dalam pergerakan tubuh penari, khususnya pada ragam-ragam gerak yang bukan postur tubuh normal. Kemungkinan terjadinya cidera bisa tinggi jika ragam-ragam gerak tersebut tidak dilatih secara tepat. Penelitian ini menggambarkan perubahan posisi titik pinggung penari Bapang Malangan yang dikenal sebagai tarian dinamis, dan memetakan beban yang terbaca pada tiap posisi gerakan. Penelitian dilakukan dengan cara merekam penari di atas landasan ukur beban.Data berupa hasil render foto dari video rekaman. Diambil10 posisi pertama dari 100 gambar pertama, dengan selang 10 frame dari total 9800 frame render. Data dianalisis perubahan titik pinggul kiri dan kanan dan dikorelasikan dengan pembacaan beban yang terjadi. Hasil penelitian menunjukkan bahwa ada posisi-posisi dimana titik pinggul kiri dan kanan terbaca terletak pada 1 koordinat. Hal ini menunjukkan bahwa posisi tersebut merupakan posisi dimana tubuh berfigur ekstrim yang berpotensi mengakibatkan cidera. Hasil penelitian belum bisa membedakan dan menggambarkan pembebanan pada tiap titik pinggul karena keterbatasan alat ukur.
\end{abstract}

Kata Kunci: Biomekanika; Pinggul; Penari

\section{PENDAHULUAN}

Seni tari mempunyai peran dalam pengembangan kemampuan motorik, karena substansi dasar dalam pembelajaran seni tari adalah gerak (Heryudita 2016). Negara Indonesia sebagai negeri yang kaya keragaman adat, budaya dan kesenian, memiliki banyak ragam seni tari di tiap masyarakatnya, maka dari itu pendidikan tari di Indonesia sangat berkembang dan diperkenalkan ke anak dengan penciptaan tarian anak berlandaskan budaya lokal lingkungan dan alam (Mulyono et al. 2018).

Seni tari mempunyai peran dalam pembentukan pribadi siswa yang harmonis. Pemberian pengalaman seni tari pada anak menjadi fungsional untuk mengembangkan berbagai kemampuan yang mempengaruhi sikap mental siswa dalam mempersiapkan diri. Hidayat (2005) menyatakan bahwa seni tari merupakan ungkapan gerakan-gerakan tubuh manusia secara ekspresif yang ditetapkan secara kultural, mengandung ritme, memiliki nilai estetika dan potensi simbolik. Sebuah tarian adalah kumpulan dari berbagai macam unsur yakni:

1. wiraga (seni tari harus menonjolkan gerak anggota badan berupa kepala, tangan dan kaki),

2. wirama (seni tari harus memiliki ritmis yang sesuai dengan irama pengiringnya).

3. wirasa (seni tari harus mampu memunculkan rasa yang diresapi pada saat menari).

Ketiga unsur tersebut menyatu dan menjadikan tarian indah dan serasi.

Seni tari sendiri memiliki beberapa pengertian dari beberapa orang yang berbeda. Soedarsono dalam (Purwatiningsih 2004) berpendapat bahwa tari adalah gerak yang ritmis. Definisi ini mengandung dua unsur yaitu unsur gerak dan ritme. Gerak dalam tari tidak bisa asal bergerak, akan tetapi harus diungkapkan secara ritmis sehingga memunculkan karakteristik tertentu yang sesuai dengan kualitas ritme yang 
Jurnal Kejaora: Jurnal Kesehatan Jasmani dan Olah Raga

ISSN: 2541-5042 (Online)

ISSN: 2503-2976 (Print)

Volume 5 Nomor 2, Edisi November 2020

dimunculkan. Seperti halnya juga yang dikatakan Kussudiardjo (1981), seni tari adalah keindahan anggota-anggota badan manusia, yang bergerak, berirama dan berjiwa. Dapat diberi arti bahwa seni tari adalah keindahan bentuk dari anggota badan manusia yang bergerak, berirama dan berjiwa harmonis. Seni tari selalu menggunakan media badan atau tubuh untuk mengungkapkan ekspresinya dalam bentuk gerak yang ritmis.

Seni tari adalah bentuk seni yang menggunakan gerak tubuh sebagai alat berekspresi, juga bisa menjadi aktivitas yang mengandung unsur kesehatan. Tari telah digunakan sebagai senam otak berbasis gerak tradisi berkoordinasi asimetris bagi anak berkebutuhan khusus (Triana and Husni 2017). Tari mempunyai arti penting dalam kehidupan manusia karena dapat memberikan berbagai manfaat, dari fungsi hiburan hingga sarana komunikasi. Tari adalah alat ekspresi dan sarana komunikasi seorang seniman kepada orang lain, penonton atau penikmatnya (Jazuli 1994).

Dalam menari atau melakukan pergerakan lain seperti senam, olahraga dan lain-lain, diperlukan kehati-hatian serta perlu dilakukan secara seimbang. Sajoto (1988) mengemukakan tentang letak titik berat badan yang lebih dikenal dengan istilah keseimbangan, sebagai kemampuan seseorang mengendalikan organ-organ syaraf ototnya selama melakukan gerakangerakan yang cepat dengan perubahan letak titik berat badan yang cepat pula, baik dalam keadaan statis maupun (terlebih) dalam gerakan dinamis. Keseimbangan tubuh adalah kemampuan untuk mempertahankan sikap tubuh tetap stabil dalam keadaan diam, berdiridengan posisi satu kaki dan kedua tangan berada di pinggang, yang diukur dalam detik (Santika, Adiatmika, and Purnawati 2015). Keseimbangan tubuh dikatakan lebih baik jika mampu mempertahankan posisi tersebut lebih lama. Jika dikhususkan pada pinggul, perhatian perlu difokuskan dikarenakan terdapat sambungan pinggul (hip joint) yang merupakan sendi penting dalam sistem kerangka manusia. Sambungan ini terletak diantara pinggul dan pangkal tulang paha

atas. Di dalam sendi pinggul terdapat tulang rawan, permukaannya sangat halus serta tidak mempunyai saraf, sehingga pergerakannya pun juga mulus.

Potensi cidera pada sistem kerangka otot bertambah secara bertahap sebagai akibat dari trauma kecil yang terus menerus yang disebabkan oleh disain yang buruk pada alat/sistem kerja yang membutuhkan gerakan tubuh dalam posisi tidak normal (Anjasmoro 2017). Cidera bisa diakibatkan oleh 3 penyebab yaitu penggunaan gaya yang sangat berlebihan selama gerakan normal, gerakan sendi yang kaku tidak pada posisi normal, dan perulangan gerakan yang sama secara terus menerus. Dari tiga penyebab cedera akibat gerakan yang tidak normal, gerakan dalam tarian, olahraga, dan senam berpotensi tinggi mengakibatkan cedera bila tidak dilakukan secara seimbang. Harsono (1988) mengemukakan bahwa keseimbangan (balance) adalah kemampuan untuk mempertahankan sistem neuromuskular dalam kondisi statis, atau mengontrol sistem neuormuskular tersebut dalam suatu posisi (sikap) yang efisien selagi bergerak.

Jawa Timur mempunyai beberapa macam tarian. Salah satu daerah yang kaya akan seni tari adalah Kota Malang. Seni tari Kota Malang yang berjenis tarian unik dan menjadi kekayaan seni khas daerah adalah Tari Beskalan, Tari Bedayan, Tari Grebeg Wiratama, dan Tari Bapang Malangan.

Tari Bapang adalah tari khas daerah Malang yang menggambarkan polah salah satu tokoh drama tari topeng (Fauzia 2018). Tokoh ini dikenal dengan sebutan Jayasentiko, seorang bupati dari Kadipaten Banjarpatoman. Kadipaten ini berada di bawah kekuasaan Raja Klono Sewandono. Tarian ini berkarakter gagah, ditandai dengan bentangan tangan lebar, mengangkat salah satu kaki dan dengan topeng yang memiliki mata lebar. Ciri mata lebar ini disebut telengan. Ciri yang khas pada bentuk topeng bapang adalah hidungnya mancung.Tari topeng bapang itu lepas dan lucu, membuat penonton terpingkal-pingkal karena ulah dan model gerakannya, tapi hal ini sangat tergantung pada tabuhan pengrawit dan pengendang yang mengiringinya, yang 
Jurnal Kejaora: Jurnal Kesehatan Jasmani dan Olah Raga

ISSN: 2541-5042 (Online)

ISSN: 2503-2976 (Print)

Volume 5 Nomor 2, Edisi November 2020

dikenal dengan istilah tabuhan dol tinuku. Tari Bapang keluar dari pakem dan struktur ragam gerak tari yang sudah ada selama ini, karena tidak semua tarian diringi karawitan langsung. Saat ini gerak tarinya dibakukan dengan gending pengiring yang terekam.

Menurut Hidayat (2008) tari topeng malangan yang juga merupakan pecahan dari wayang topeng adalah pertunjukan khas yang berasal dari Kota Malang. Tari ini bisa dikatakan seni tari-drama karena di dalam tarian ini terdapat drama yang ditampilkan oleh penari dengan gerakan-gerakan simbolis aksesoris topeng. Tari topeng diibaratkan sebagai seorang ksatriya yang gagah dengan karakter bringas, menekankan keindahankeindahan dan ketegasan dari gerakannya itu sendiri sebagai makna-makna simbolik. Menurut Endryanti (2015), ada dua puluh satu macam gerak penghubung dari tari topeng. Untuk tari topeng bapang dikenal gerak siring, njluwat, ngglebak, singgget, nigas, ngancap, ngapurancang, ongkekan, ngunting, lembehan, penthangan, nggethak, mengkal, pusingan, gedruk gawang, gedruk entram, banyak dhidis, jalak kecancang, minyak slambu, dan godhek siwur putul.

Penari bapang mengenakan topeng berwarna merah, berhidung mancung, dengan rincian kostum terdiri atas Jamang, Topeng, Kalung kace, Kelat Bahu, Stagen, Sabuk timang, Rapek ngarep, Rapek mburi, Pedangan, Gelang deker, Kasut (kaus kaki), dan Gongseng. Pengenaan jamang (mahkota) pada topeng bapang dipasangkan terbalik yang dituturkan sebagai sifat congkak, kocak,dan berangasan. Tarian bapang diringi dengan permainan gamelan lengkap untuk memainkan gending kalongan laras pelog patet bem. Gending ini juga disebut gending kempul papat karena dalam satu gongan terdapat empat kali pukulan kempul.

Dari keempat tarian unik Kota Malang tersebut, analisa pergerakan pada pinggul penari diambil dari Tari Bapang Malangan dikarenakan kemudahan akses dan penarinya tersedia.

\section{METODE}

Penelitian ini dilakukan pada bulan Mei-Juni 2020. Lokasi penelitian adalah

Padepokan Seni Mangun Dharma berlokasi di JL. Raya Mangun Dharmo 08 RT 28/RW03 Dukuh Kemulan, 65156, Krajan, Tulus Besar, Tumpang, Malang.

Penelitian ini adalah penelitian eksperimental biomekanika non destruktif yang menggunakan data dari hasil rekaman gerak tari Bapang Malangan. Penelitian dilakukan dengan cara merekam penari di atas landasan ukur beban (floor scale). Pengambilan data dimulai dengan mengukur berat tubuh penari dengan dan tanpa kostum (Gambar 2). Namun demikian, data yang dibahas di sini adalah data penari tanpa menggunakan kostum.

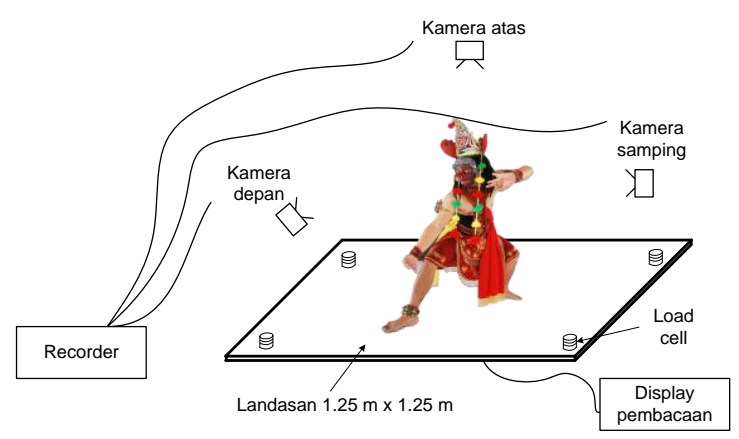

Gambar 1. Floor scale biomekanik, yang berprinsip sama dengan timbangan badan skala besar. Alat ini memiliki 4 loadcell yang merupakan sensor berat, terletak di 4 titik tumpuan landasan. Luasan landasan adalah $1.25 \times 1.25 \mathrm{~m}$, diberi garis-garis jala sebagai penanda jarak langkah gerakan (Finahari, Rubiono, and Qiram 2020)

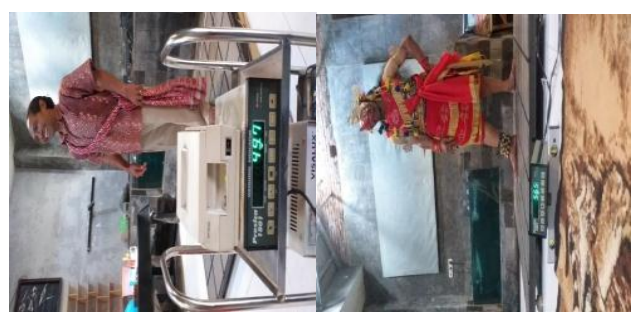

Gambar2. Mengukur beban penari

Data untuk analisis berupa hasil render foto dari video rekaman. Diambil 10 posisi pertama dari 100 gambar dengan selang 10 frame dari total 9800 frame render. Data dianalisis perubahan titik pinggul kiri dan kanan dan dikorelasikan dengan pembacaan beban yang terjadi. 
Jurnal Kejaora: Jurnal Kesehatan Jasmani dan Olah Raga

ISSN: 2541-5042 (Online)

ISSN: 2503-2976 (Print)

Volume 5 Nomor 2, Edisi November 2020

Pengukuran posisi didapatkan dari analisis program aplikasi ImageJ ver. 2.0. Data hasil pengukuran beban didapat dari rekaman displai pengukuran beban yang terbaca pada floor scale. Data-data tersebut kemudian digrafikkan sebagai grafik berbasis waktu (time series) yang menunjukkan karakteristik perubahan beban pinggul penari saat menggunakan kostum dan tidak menggunakan kostum.

\section{HASIL DAN PEMBAHASAN}

Data beban diperoleh dari pengolahan data rekaman video penari di atas landasan Floor Scale. Rekaman video tersebut berkualitas 25 fps (frame per second),
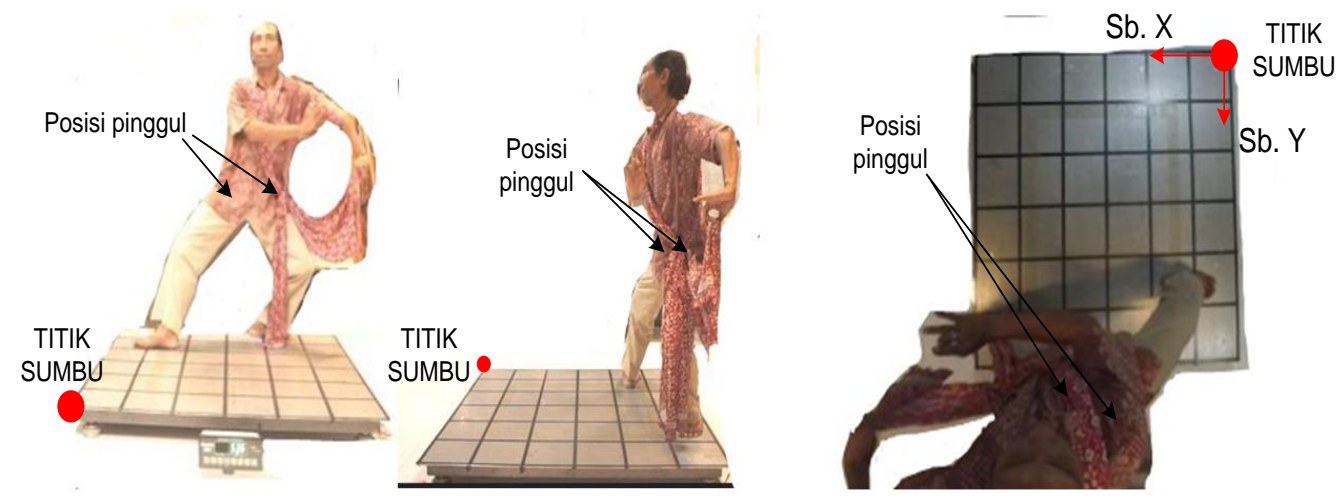

Gambar 3. Arah perekaman video (depan, samping dan atas), penentuan titik-titik ukur dan acuan sumbu koordinat

Tabel 1. Hasil Pembacaan Gambar

\begin{tabular}{ccccccccccc}
\hline \multirow{2}{*}{ Sumbu Pinggul } & 1 & 2 & 3 & 4 & 5 & 6 & 7 & 8 & 9 & 10 \\
\hline X kiri & 103 & 103 & 107 & 101 & 132 & 101 & 166 & 90 & 22 & 60 \\
Y kiri & 167 & 147 & 151 & 152 & 166 & 149 & 161 & 148 & 154 & 134 \\
Beban & 53,5 & 54,1 & 54,1 & 55,5 & 55,5 & 55,8 & 56 & 59,6 & 56,8 & 56,5 \\
X kanan & 75 & 75 & 76 & 87 & 116 & 118 & 167 & 88 & 23 & 40 \\
Y kanan & 161 & 122 & 135 & 136 & 136 & 136 & 136 & 133 & 141 & 135 \\
\hline
\end{tabular}




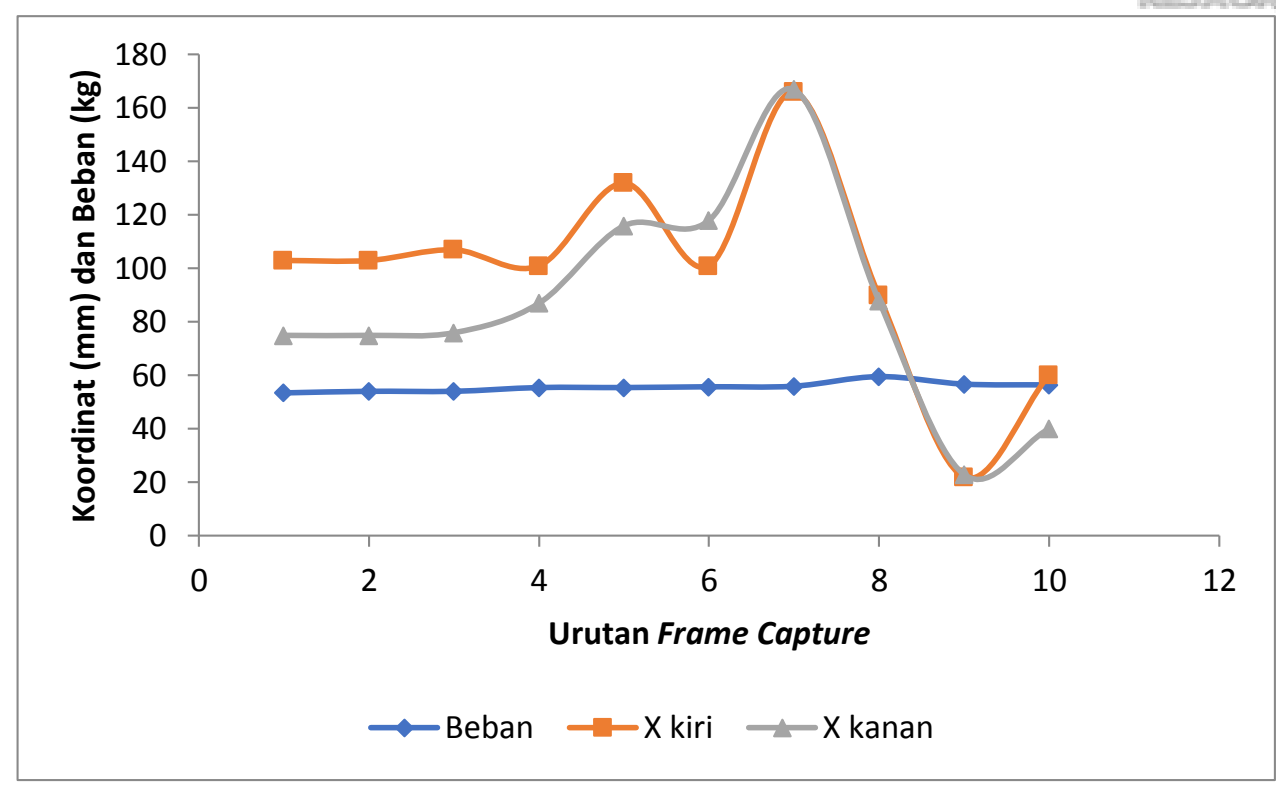

Gambar 4. Posisi titik pinggul di arah sumbu X dengan pembacaan beban pada floor scale.

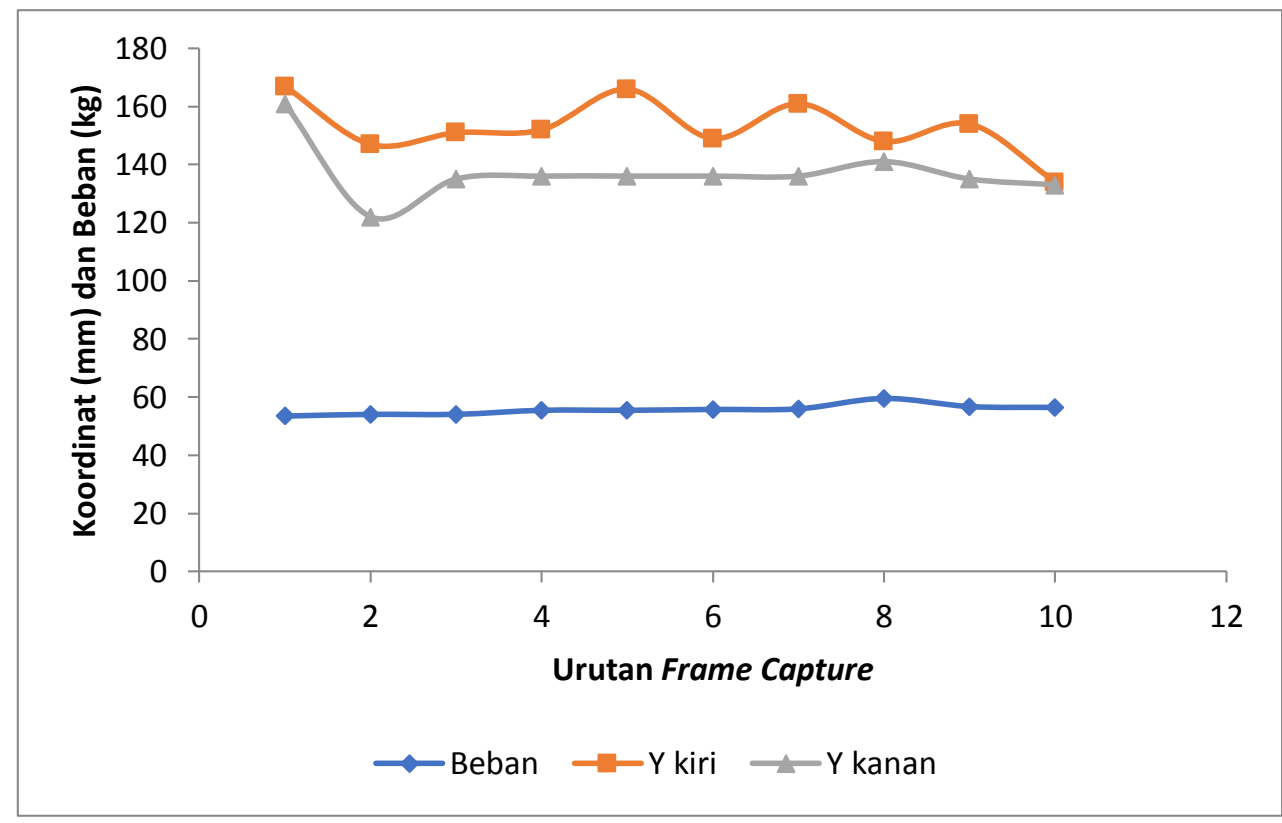

Gambar 5. Posisi titik pinggul di arah sumbu $Y$ dengan pembacaan beban pada floor scale.

Data pada Tabel 1 dijadikan grafik sebagaimana tampak pada Gambar 4 dan 5 . Tampak bahwa baik pada sumbu $X$ maupun $Y$, titik pinggul kiri dan kanan menyatu. Hal ini bisa diartikan bahwa posisi pinggul kiri dan kanan terletak pada satu garis sumbu pada arah pandangan pengukuran. Posisi ini menunjukkan potensi cidera pada tubuh, khususnya pada sendi pinggul, yang diakibatkan oleh salah posisi.
Berdasarkan pendapat dari Zulfaa (2011), rasa nyeri pinggul dapat dirasakan sebagai akibat dari tarikan/sprain (cedera pada tulang sendi), cedera (kecelakaan atau saat berolahraga, kerusakan otot, patah tulang akibat osteoporosis, penyakit peradangan seperti arthritis, kanker (misalnya kanker prostat), infeksi kandung kemih, dan infeksi tulang punggung seperti tuberculosis. Dengan dasar tersebut pergerakan tari harus dilakukan hati-hati ketika bergerak di pagian 
Jurnal Kejaora: Jurnal Kesehatan Jasmani dan Olah Raga

ISSN: 2541-5042 (Online)

ISSN: 2503-2976 (Print)

Volume 5 Nomor 2, Edisi November 2020

pinggul, dikarenakan potensi besar rentan patah. Otot gluteus medius merupakan otot yang berperan penting dalam pergerakan pinggul. Kurang terlatihnya otot tersebut dapat dengan mudah menyebabkan cedera. Otot gluteus medius berperan dalam menjaga keselarasan panggul ketika melakukan gerakan melompat, mendarat, menendang, dan lain-lain.

Nyeri punggung bawah memiliki gejala berupa nyeri di bagian pinggang yang dapat menjalar ke tungkai kanan atau kiri (Winata 2014). Nyeri ini umumnya pernah dirasakan oleh setiap orang. Nyeri punggung bawah sering terjadi pada individu yang melakukan aktivitas berdiri atau duduk dalam jangka waktu yang lama, banyak mengangkat beban berat dengan posisi yang salah. Sekali lagi, posisi tubuh yang salah bisa menjadi sumber cidera.

Dari aspek pembebanan, tampak bahwa beban yang tertangkap pada layar floor scale tidak berubah secara signifikan selama pergerakan 100 frame tersebut. Teridentifikasi adanya perubahan hadapan dan tumpuan kaki pada rentang 100 frame tersebut. Beban yang terbaca tidak menggambarkan perubahan tumpuan tersebut. Hal ini juga tidak menggambarkan beban yang ditanggung masing-masing titik pinggul selama terjadinya perubahan pergerakan, meskipun titik pinggul kanan dan kiri berubah cukup ekstrim di sumbu $X$. Kelemahan penelitian ini tergambar di bagian ini.

\section{KESIMPULAN}

Hasil penelitian ini menunjukkan adanya ekstrimitas perubahan figur tubuh yang diindikasikan oleh perubahan posisi titik pinggul pada sumbu $X$ dan $Y$. Perubahan posisi tersebut belum bisa membedakan dan menggambarkan pembebanan pada tiap titik pinggul. Hal ini disebabkan oleh keterbatasan alat ukur.

Perlu dilakukan sistem pengukuran langsung atau didesain alat yang bisa mengukur secara langsung pada bagian pinggul kanan dan kiri sehingga semua pergerakan yang terjadi pada pinggul dapat terbaca/terekam dengan detail. Peralatan ini

sebaiknya bersifat nirkabel sehingga tidak terganggu gerakan dinamis penari.

\section{UCAPAN TERIMA KASIH}

Penelitian ini merupakan bagian dari penelitian dosen dalam skema Penelitian Dasar Hibah Kompetitif Nasional DRPM DIKTI tahun anggaran 2020 yang telah dijadikan skripsi dan lulus diujikan untuk level Sarjana Strata 1 Teknik Mesin (S1).

\section{DAFTAR PUSTAKA}

Anjasmoro, T. 2017. Implementasi Program Keselamatan Dan Kesehatan Kerja Dalam Upaya Mempertahankan Zero Accident Di PADA PT Dua Kelinci. Semarang.

Endryanti, Ella Rizky. 2015. "Analisis MorfoSemantis Nama-Nama Ragam Gerak Tari Topeng Bapang Di Kecamatan Pakisaji Kabupaten Malang." UGM Yogyakarta.

Fauzia, Irma. 2018. "Temu Topeng Malang, Tari Topeng Bapang Diperdebatkan." Akurat.Co. Retrieved July 15, 2020 (https://akurat.co/hiburan/id-264277read-temu-topeng-malang-taritopeng-bapang-diperdebatkan).

Finahari, Nurida, Gatut Rubiono, and Ikhwanul Qiram. 2020. Studi Potensi Resistensi Dan Rapid Recovery Penari Terhadap Paparan Covid-19 Sebagai Wujud Respon Psikoakustik Kumulatif Dari Sinyal Kombinasi Suara Gending Dan Gerak Tari. Malang.

Harsono. 1988. Coaching Dan Aspek-Aspek Psikologi Dalam Coaching. Jakarta: Depdikbud Dirjen Dikti.

Heryudita, Karifa. 2016. "Peran Pembelajaran Seni Tari Dalam Pengembangan Kemampuan Motorik Siswa Di SD Negeri Slerok 4 Kota Tegal." Univ. Negeri Semarang.

Hidayat, R. 2005. "Wawasan Seni Tari." Fakultas Sastra Univ. Negeri Malang.

Hidayat, R. 2008. Wayang Topeng Malang. Malang: Gantar Gumelar.

Jazuli, M. 1994. Telaah Teoritis Seni Tari. Semarang: IKIP Semarang Press.

Kussudiardjo, Bagong. 1981. Tentang Tari. Yogyakarta: PT Nur Cahaya. 
Jurnal Kejaora: Jurnal Kesehatan Jasmani dan Olah Raga

ISSN: 2541-5042 (Online)

ISSN: 2503-2976 (Print)

Volume 5 Nomor 2, Edisi November 2020

Mulyono, Untung, Subowo Y, and Sukotjo. 2018. Penciptaan Tarian Anak Berdasarkan Budaya Lokal Lingkungan Dan Alam. Yogyakarta.

Purwatiningsih, Harini N. 2004. "Pendidikan Seni Tari Drama Di TK-SD Malang." Universitas Negeri Malang.

Sajoto, Moch. 1988. Pembinaan Kondisi Fisik Dalam Olahraga. Jakarta: Depdikbud Dirjen Dikti.

Santika, I. G. P. Ngurah Adi, I. P. G. Adiatmika, and Susy Purnawati. 2015. "Pelatihan Berjalan Di Atas Balok Lurus Sejauh 8 Meter 5 Repetisi 4 Set Lebih Baik Daripada 4 Repetisi 5 Set Terhadap Keseimbangan Tubuh Mahasiswa Fakultas Pendidikan Olahraga Dan Kesehatan IKIP PGRI Bali." Sport and Fitness Journal 3(1):1-7.

Triana, Dinny Devy, and Eddy Husni. 2017. "Senam Otak Berbasis Gerak Tradisi Koordinasi Asimetris Bagi Anak Berkebutuhan Khusus." Sarwahita: Jurnal Pengabdian Kepada Masyarakat 14(1):10-20.

Winata, Handy. 2014. "Hipermobilitas Sendi Pada Anak-Anak Dengan Idiopatik Skoliosis." J. Kedokt Meditek 20(52):28-35.

Zulfaa, Aishiiz. 2011. "Pengaruh Pemberian Stretching Pada Otot Gastroknemius Dan Otot Hamstring Terhadap Keseimbangan Dinamis Pada Lansia." FIK Unmuh Surakarta. 